\title{
The east-alpine earthquakes and the seismicity associated with the contact zone between the bohemian massif and the carpathians
}

\author{
A. ZÁTOPEK (*)
}

Receveid on October 18 th, 1977

\begin{abstract}
Riassunto - I terremoti che hanno origine nella regione alpino-orientale si propagano verso nord attraverso il massiccio Boemo pressoché asismico, con attenuazione di energia anomalamente piccola. Questa energia è guidata nelle zone che sono in corrispondenza della struttura del blocco profondo del massiccio Bocmo. A contatto della zona fra il massiccio Boemo ed il sistema dei Carpazi sismicamente attivo sembra esservi una barriera per l'energia. La zona di contatto si è formata su blocchi della crosta insediati più profondamente ed è notevole per anomalie gravimetriche e geomagnetiche. Tale zona è divisa a nord-ovest dalla zona di faglia di Lednice, che è sismicamente inattiva, e, a sud-est, dalla parafora Peripiennina, una zona di faglia pronunciata che penetra attraverso la crosta terrestre ed è caratterizzata, nel lato più profondo dell'arco Carpatico, da una sismicità relativamente alta. Il lato esterno della parafora Peripiennina mostra una linea di inversione dei vettori di induzione di Wiese straordinariamente pronunciata, il che corrisponderebbe all'effetto di un conduttore a corrente elettrica lineare con l'asse giacente parailelamente alla parafora Peripiennina a $20-50 \mathrm{~km}$ di profondità.

Questa zona anomala di conduttività elettrica differisce chiaramente dal campo di conduttività largamente esteso e tettonicamente orientato in questa parte del continente Europeo.
\end{abstract}

SUMMARY - Earthquakes originating in the east-alpine region are propagated northwards through the seismically relatively quiescent Bohemian Massif with anomalously slow attenuation of their energy. The latter is guided in the zones corresponding to the deep blok structure of this tectonic unit. A kind of barrier appears for the energy of east-alpine earthquakes at the contact zone between the Bohemian Massif and the seismically active system of the Carpathians. The

(*) Institute of Geophysics, Charles University, Praha, Czechoslovakia. 
contact zone is built up of deeper seated blocks of the crust and is conspicuous by gravimetric, geomagnetic and geoclectric anomalics. It is separated from the Bohemian Massif in the north-west by the zone of Lednice, a deep fault zone which is scismically inactive, and from the inner West Carpathians in the south east by the Peripieninian lineament, a pronounced fault zone penetrating through the crust and characterized, mainly on the inner side of the Carpathian arc, by a relatively high degree of seismicity. The outer side of the Peripieninian lineament displays a strikingly pronounced line of inversion of Wiese induction vectors, which would correspond to the effect of a linear electric current conductor with the axis lying parallelly to the Peripieninian lincament in a depth of $20-40 \mathrm{~km}$. This anomalous zone of electric conductivity differs clearly from the widely exstended and tectonically oriented conductivity field in this part of the European continent.

\section{INTRODUCTION.}

The aim of the present paper is to demonstrate more in detail different types of seismic activity and a peculiar form of propagation of seismic energy generated in the east-alpine foci through the Bohemian Massif. In the same time a quite different behaviour will be shown as regards the propagation of the energy of east-alpine earthquakes into the Carpathians.

Facts known from seismological observations will be presented with some results of explosion seismology and geophysical synthesis available for the region in question. Special, attention will be paid to the contact zone between the Bohemian Massif and the West Carpathians, as this zone has been subject to extensive geophysical investigation.

Our region of interest represents a part of Central Europe situated (Fig. I) south of the practically aseismic Paleozoic Polish platform PP. It contains the tectonic unit of the epi-Variscan Bohemian Massif BM (including in the north-west the adjacent Saxo-Thuringicum ST) with a minor degree of seismic activity, and two seismically active young zones shaped substantially during the period of the Tertiary folding, i. e. the East Alps EA and the western part - the West Carpathians - of the Carpathian system CS, encircling the Pannomian (Carpathian) basin PB. The development of the last named units is still going on. 


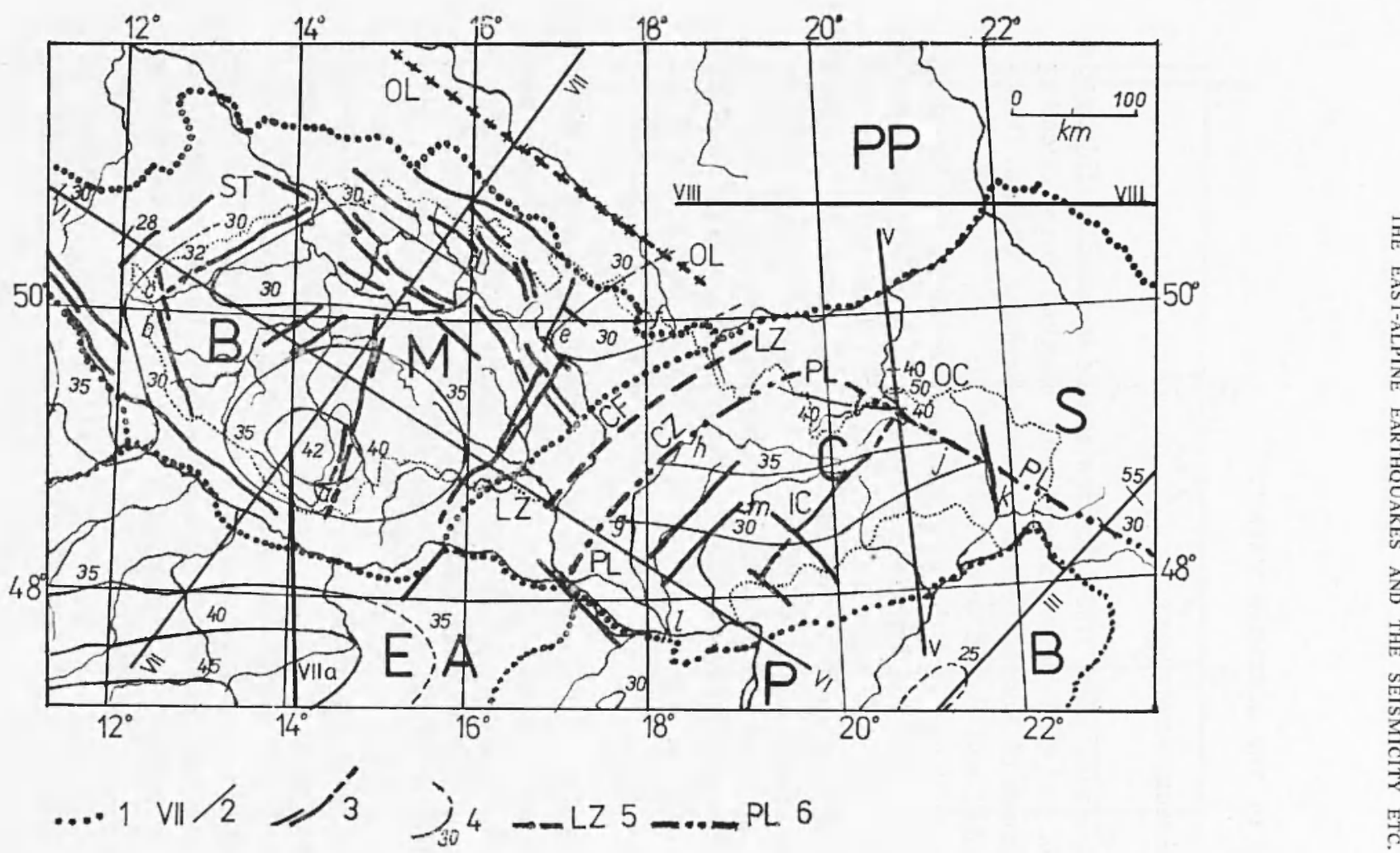

Fig. 1. Region of the Bohemian Massif and the West Carpathians: 1 - boundaries of tectonic units; 2 - international deep seismic sounding profiles; 3 - surface fault systems; 4 - depths of the Moho; 5 - Lednice zone; 6 - Peripieninian lineament; OL - Odra (Oder) line; BM - Bohemian Massif; ST - Saxo-Thuringicum; EA - East Alps; CS - Carpathian System; PB - Pannonian basin; PP - Polish Paleozoic platform; OC - Outer Carpathians; IC - Inner (Central) Carpathians; CF Carpathian foredeep; $\mathrm{CZ}$ - contact zone between the Bohemian Massif and the Carpathians; ( $a-f)$-epicentral areas in the Bohemiam Massif; $(g-l)$-epicentral areas in the West Carpathians. 
SEISMICITY OF THE BOHEMIAN MASSIF.

\section{Autochthonous earthquakes.}

The Bohemian Massif (the Saxo-Thuringicum included) is dislocated in Bohemia and NW-Moravia-Silesia with marginal parts extending to the territcries of Austria, Federal Republic Germany, German Democratic Republic and Poland (cfr. Fig. 1 and 2).

In the south-west and the west it is separated from the Mesozoic Bavarian plate by a number of faults directed $N W-S E$. In the northwest and the north its boundary is covered by Triassic sediments and mighty Quaternary deposits. In the north and north-east the Odra fault line OL represents its boundary with the Polish Paleozoic platform PP. In the south-east and the south the Bohemian Massif is bordered by the Alpine-Carpathian Neoidic fold-belt, the Neogene foredeep on which is situated over the submerged parts of the Massif. In the case of the West Carpathians it is the Carpathian foredeep CF and the contact zone $\mathrm{CZ}$.

Tcctonically the Bohemian Massif represents a complicated horstlike blok structure of the ancient European plate affected by the preCabrian and Caldedoniam oregenies with various forms of volcanism; the development of the Massif culminated in the Variscan oregeny during the Late Paleozoic. Its individual structural units were subject to a sequence of uplifts along steep systems of faults. The stabilization taking place since the end of the Variscan tectonic era (about in the Middle Permian) was the reason that the Bohemian Massif was exposed to a long-lasting denudation and peneplanation of its surface. The inner consolidation in the almost vertical fault zones continued until the Neogene. Then the effect of the Alpine orogeny resulted in the first place in the pressure, directed from the south to the north, which led, mainly at the periphery of the Bohemian Massif, to the forming of radial faults and a re-juvenation of some fault zones established earlier. This was often connected with neovolcanic activity (Miocene), in the first place along the $S W-N E$ fault system at the southern border of the Ore Mountains (Krusne hory, Erzegebirge) and the $N W$-SE faults along the $N E$-margin of the Massif. A lifting up of the Bohermian Massif as a whole and 


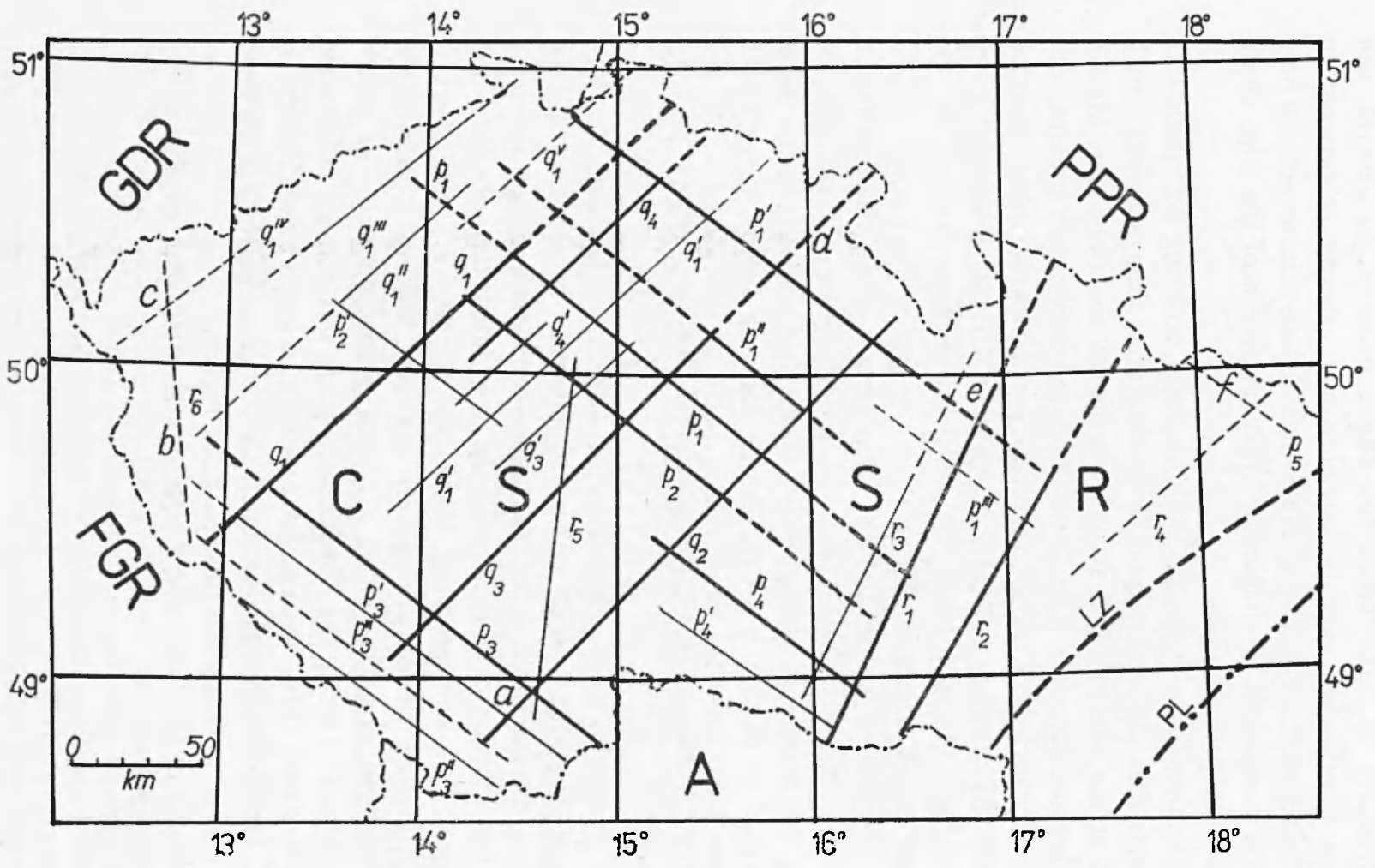

Fig. 2. Axes of zones of higher seismic mobility in the Bohemian Massif: $p-S W-N E$ belts; $q-N E-S W$ belts; $r-$ radial belts; LZ - Lednice fault zone; PL - Peripieninian lineament, A - Austria, FGR - Federal Republic Germany, GDR - German

- Democratic Republic, CSSR - Czechoslovak Socialist Republic; PPR - Polish Popular Republic; heavy lines - axes with deterinined dispersion; light lines - axes without determined dispersions; dashed lines — supplements derived from data of the Friuli main shock on 6 May. 1976. 
sedimentation in the inner depressions in South-, NE- and North Bohemia are characteristic for this youngest period of evolution.

With regard to earthquakes, the alpine pressure, in general, can be seen as a primary cause of autochthonous shocks originating in the Bohemian Massif. In this sense the autochthonous seismic activity here may well be considered as «induced» by the evolution of the Alps continuing until the present time.

The earthquake catalogue of Czechoslovakia, covering the epoch 4601956, reveals that the observations of earthquakes, though mostly small, originated at the margins and in the interior of the Bohemian Massif, were much more frequent than it was believed before. At present, this fact is also confirmed by a high number of micro-earthquakes recorded in the stations Pruhonice $\left(49^{\circ} 59.3^{\prime} \mathrm{N}, 14^{0} 32.5^{\prime} \mathrm{E}\right)$ and Kasperske Hory $\left(49^{\circ} 07.8^{\prime} \mathrm{N}, 13^{0} 34.8^{\prime} \mathrm{E}\right)$, many of which have been located in the central part of the Bohemian Massif.

The grouping of historical foca! areas occurs along the reactivated fault zones in the peripheral parts of the Bohemian Massif. In the interior of the Massif an accumulation of the foci appears in the areas $a-f$ plotted in Fig. 1: $a-$ the South Bohemia basins, $b-$ Czech great quartz lode, $c$ - the Cheb (Eger) basin and Vogtland, $d-$ the Upa (Aupa) valley region, $e-$ the border zone Moravia-Silesia, $f-$ the Opava region.

Apart from the great earthquake of 1872 near Gera at the NW boundary of the Massif with epicentral intensity reported $8^{0}$ of the international macroseismic scale, the effects of which weree relatively small in the interior of the Massif, the top intensities observed are mostly below $7^{0}$, i. e. magnitudes $M \doteq 5$ (see Kärník, V., 1968, Part I, pp. 48-50). Groups of earthquakes are not rare. Swarms occur in the region $a$, and are world-known as a typical phenomenon in the region $c$ with $I_{0} \max =7^{\circ}$. During the last hundred years this activity culminated in this region round 1910. Some of these swarms included several hundreds of shocks. This points out the weakness of couplings between individual blosks of this tectonically heavily fractured region.

All shocks in the Bohemian Massif are shallow with depths mostly less then $10 \mathrm{~km}$. 

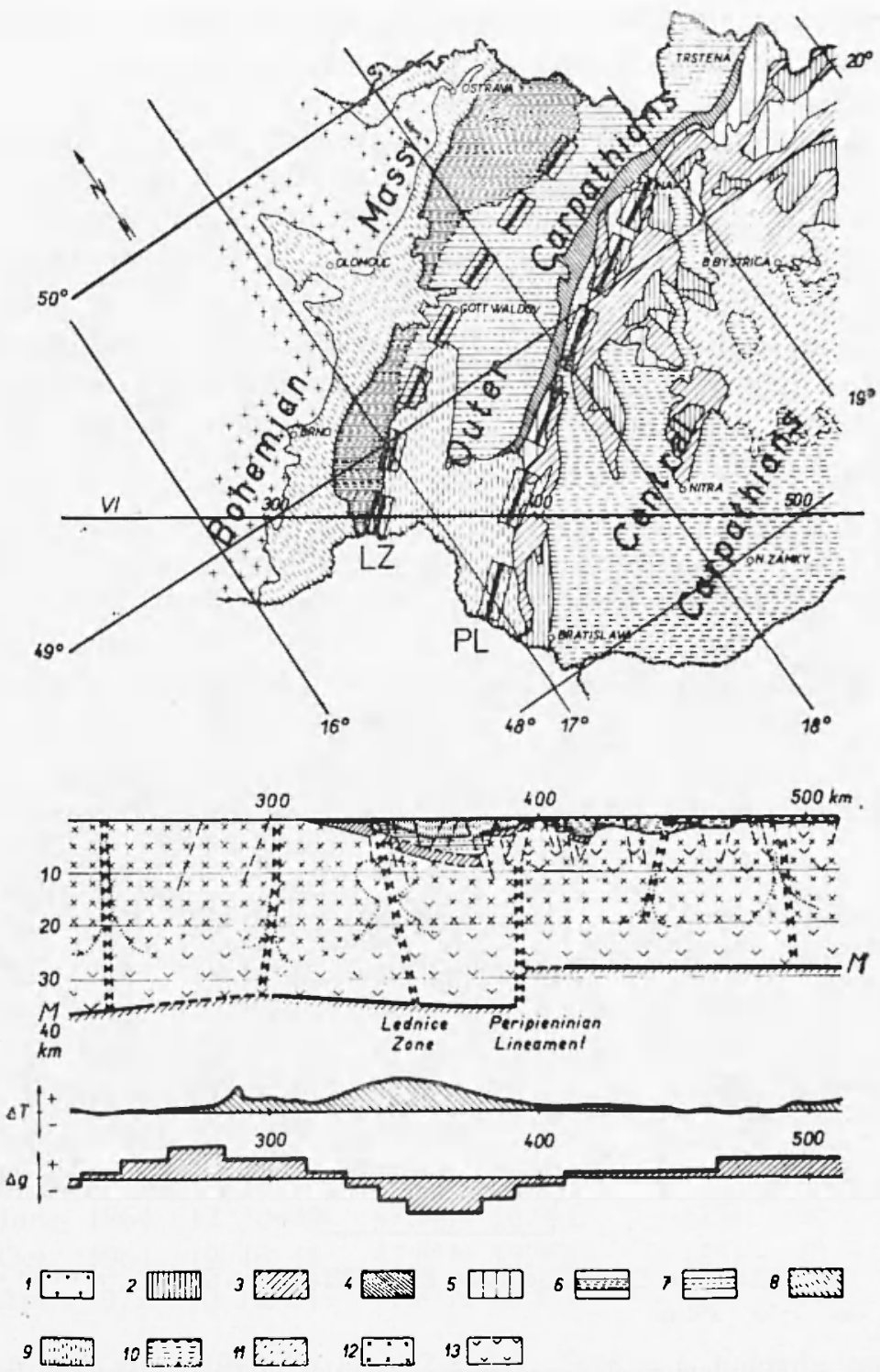

Fig. 3. Contact zone between the Bohemian Massif and the Carpathians: top - geologicalscheme; middle - structural cross-section, showing sedimentary, granitic and basaltic crustal layers and deep fault zones ascertained by DSS; botton: $\Delta T^{\prime}=$ anomaly of total geomagnetic field $T ; A g=$ Bouguer gravity anomaly, $\Delta T$ and $\Delta g$ given in arbitrary units; 1 - formations of the Bohemian Massif; 2 granite; 3 - Mesozoic of the Inner Carpathians; 4 - cliff (Klippen) belt; 5 Paleogene; 6,7 - Flysch belts; 8,9 - Neogene, 10 - Tertiary filling of the inner basins; 11 - neovolcanics; 12 - granitc layer; 13 - basaltic layer. 
2. Anomalous propagation of the east-alpine earthquakes through tine Bohemian Massif.

An important role in the seismic mobility is to be ascribed to the major earthquakes generated in the East Alps and propagated to the north and north-west throughout the Bohemian Massif. Most of them are ccming from the sharply distinguished seismogenetic fault zone which proceeds across the superficial geological structures from the Carnc and Julian Alps in NE Italy toward the northeast along the valleye of the rivers Mur, Mürz and Leitha and ends at the Danube in the contact area with the West Carpathians Varník, V., 1968 e1971; Sieberg, A., 1932 and cf. F.g. 4).

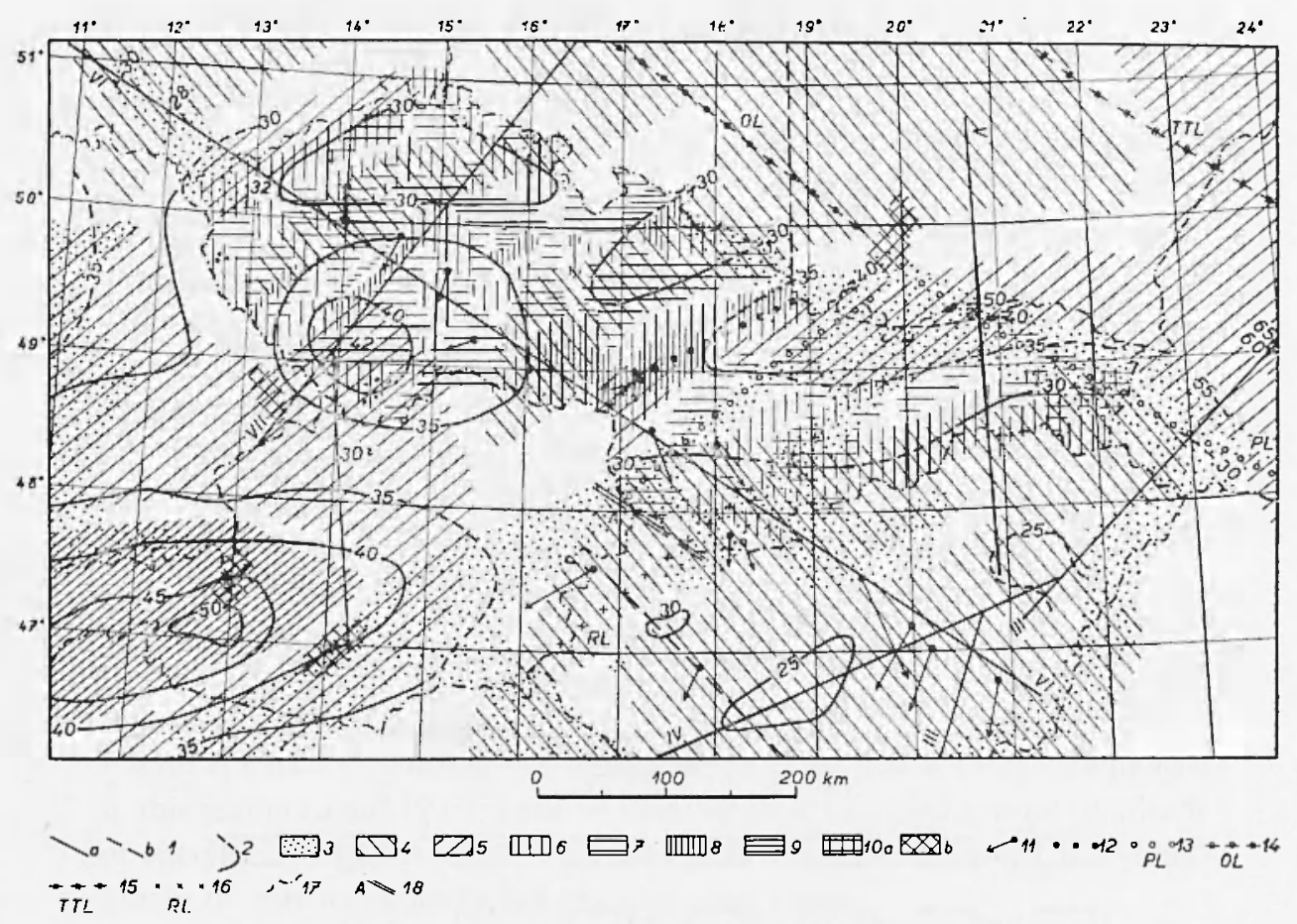

Fig. 4. Distribution of some geophysical fields in Central Europe: la, $b-$. deep seismic sotunding profiles; 2 -. depths of the Moho; 3 - seismically active zones; 4 - positive gravity anomalies; 5 - negative gravity anomalies (denser hatching signifies $|\Delta \mathrm{g}| \geqq 100 \mathrm{mgl} ; 6$ - positive geomagnetic anomalies; 7 - negative geomagnetic anomalies; 8 - zones of high positive geomagnetic anomalies; 9 - zones of high negative geomagnetic anomalies; $10 \mathrm{a}$ - areas of high geomagnetic anomalies in neovolcanic belts in Czechoslovakia; 10b - anomalous geomagnetic zones in Austria and Poland; 11 - magnetotelluric induction vectors along international profile VI (see also Fig. 6); 12 - fault zone of Lednice; 13 - Peripieninian lineament; 14 - Odra (Oder) lineament; 15 - Tarnqvist-Teisseyre lineament; 16 - Raab line; 17 - state Tronticrs; 18 - deep reflecting seismic interfaces suggested in (Zatopek, A., 1957). 
Since the times of E. Suess Suess, E., 1885 it became known that their macroseismic fields. These are anomalously elongated toward the north and north-west. Consequently, the pear-like shape of the macroseismically shaken area is asymmetric with the focus situated in the south-eastern part of the field. If the earthquake reaches the Bohemian Massif, the decrease $f$ macrcseismic intensities with epicentral distance becomes in generaly unusually small, much smaller than at the corresponding distance in the Carpathians or even in the Alps themselves. In this way strong east-alpine earthquakes penetrate macroseismically far over Dresden in Saxony, i. e. to epicentral distances over $400 \mathrm{~km}$.

A number of earlier authors, e.g. Heritsch, F.; Kautsky, F.; Schwinner, R.; Mifka, V., Trapp, E., tried to find an explanation of this anomaly; unfortunately, due to a relatively small number of available cbsrvational data, some erroneous results, especially for the kind of propagation in the Boemian Massif, have been obtained, cf. Zatopek, A., 1948a; 1948b.

During the last four decades many thousands of obesvational data have been cllected from the Bohemian Massif in the Geophysical Institute of the Academy of Sciences Prague, Czchoslovakia, as regards the following earthquakes occurred in the north-eastern part of the East Alps:

\begin{tabular}{|c|c|c|c|c|c|c|c|}
\hline No. & Dat & & $U T(h, m$, & & $h(\mathrm{~km})$ & $I_{0}(M S K)$ & M \\
\hline 1 & 25 July & 1927 & 213530 & $47.5^{0} \mathrm{~N} \quad 15.5^{n} \mathrm{~F}$ & $36^{(1)}$ & $7^{0}$ & 5.4 \\
\hline 2 & 8 Oct. & 1927 & 194900 & $48.1^{0} \mathrm{~N} \quad 16.4^{0} \mathrm{E}$ & $28^{(2)}$ & $7.9^{\circ}$ & 5.6 \\
\hline 3 & 8 Nov. & 1938 & $03 \quad 1134$ & $47.9^{0} \mathrm{~N} \quad 16.4^{0} \mathrm{E}$ & $25-28^{(2)}$ & $7^{0}$ & 5.3 \\
\hline $3^{\prime}$ & 8 Nov. & 1938 & $03 \quad 23 \quad 15$ & $47.9^{0} \mathrm{~N} \quad 16.4^{0} \mathrm{E}$ & & $4.5^{0}$ & \\
\hline 4 & 18 Sep. & 1939 & $00 \quad 14 \quad 37$ & $47.8^{0} \mathrm{~N} \quad 15.9^{0} \mathrm{E}$ & (25) & $7^{0}$ & (5.2) \\
\hline 5 & 2 Dec. & 1963 & $06 \quad 4909$ & $47.9^{\circ} \mathrm{N} \quad 16.4^{0} \mathrm{E}$ & (25) & $6.5^{0}$ & (5.0) \\
\hline 6 & 30 June & 1964 & $123 \mathrm{C} 02$ & $47.7^{\circ} \mathrm{N} \quad 16.0^{\circ} \mathrm{E}$ & (25) & $5^{0}$ & $(41 / 4)$ \\
\hline 7 & 27 Oct. & 1964 & 194611 & $47.8^{0} \mathrm{~N} \quad 15.9^{\circ} \mathrm{E}$ & (25) & $6^{0}$ & $(43 / 4)$ \\
\hline 8 & 16 Apr. & 1972 & 101004 & $47.8^{0} \mathrm{~N} \quad 16.1^{\circ} \mathrm{E}$ & (25) & $7.5^{0}$ & (5.5) \\
\hline
\end{tabular}

(1) Afther Karník 1968; (2) after Zatopek, 1948 a; (...) depths assumed by the author; magnitudes $M$ calculated after Karnik, 1968, Part I, p. 48.

Except the aftershock No. $3^{\prime}$ his ensemble of earthquakes revealed striking similarities of the individual macroseismic fields. Shocks No. 1-4 have been studied by the present author on a basis of almost 3000 reports from 1029 localities situated in the Bohemian Massif 
Zatopek, $1948 \mathrm{a}, \mathrm{b}$ under use of graphical and numerical statistics. Characteristic results are as follows:

a) Intensities $\mathrm{f}$ observations in a distance range from about 70 to $420 \mathrm{~km}$ distributed over the Bohemian Massif region vary irregularity and do not indicate any regular decrease with epicentral distance.

b) The density of points of observation is very variable, but the general pattern preserves a clearly pronunced stability for all the cases studied. Repeatedly certain areas are covered densily with observations while in the neighbouring zones the density of observation is very small. This fact does not depend on the epicentral distance in the given range of distances and is not directly related to the density of population.

c) In the suth-east, near the contact of the Bohemian Massif with the Carpathians the observations become scarce and practically disappear in the south-east of the line LZ - the so-called zone of Lednice - plotted in Fig. 1. The adjacent zone CZ, a contact zone between the Bohemian Massif and the Carpathians appears as a barrier for the energy of alpine earthquakes. We shall se that this zone is conspicous by geophysical effects.

d) The observations reappear at the south-western edge of the Little Carpathians, but the intensities decrease very rapidly toward the north-east, along the south-western branch of the fault zone $P L$, associated with the Peripieninian lineament, geologically known as an important disturbed zone, separating the Outer Carpathians OC (Fig. 1) frcm the Inner (or Central) Carpathians IC. This rapid attenuation of the energy penetrating into the Carpathians suggests the idea of a seismic barrier at the NE end of East Alps Zatopek, 1957.

e) By means of graphical statistics applied to the set of observation points two systems of staight lines of regression $p$ and $q$, represented in Fig. 2, were derived as axes of the zones including the majority of observation points. The directions found correspond to average main tectonic directions of the Bohemian Massif. Apart of them an accumulation of observations was found along axes denoted in Fig. 2 with $r-s$. This system corresponds to the radially disturbed zones of grabencharacter.

f) Though the pattern found coincides in general with the known 
superficial fractured zones, its geo'ogical explanation in some cases, e.g. for the densily covered zone $p_{2}$, is not evident and must be attributed to deeper seated factors.

After elimination of the influence of density of population, the densily covered zones, in view of their statistical stability, were physically interpreted as zones of higher seismic mobility. The anomalous higher energy in this interpretation is provided in greater epicentral distances by waves guided at a deeper-seated quasi-horizontal discontinuity, slowly nearing to the surface in the north; from this interface the energy is transported to the surface a'ong steeply falling deep dislocations. Therefore, on the surface, the statistically found axes of densily covered zones indicate a scheme of the deep block structure of the territory in consideration. The geologically-territorial meaning of the scheme plotted in Fig 2 was explained in detail in Zatopek, 1948 a.

These results have been confirmed and completed with a microseismic analysis on a basis of a about 4000 observations referring to the earthquakes No. 6, 7 and 8 Babska, V., Ruprechtova, L., Zenklova, O., 1965; Babuska, V., Ruprechtova, L., 1965. In Babuska, V., Ruprechtova, L., 1965 the indipendence of the density of observations from the density of population was ensured by introduction of a normalized observation-point density in a unit area.

In a map representing the density of observations in Babuska, V., Ruprechtova, L., 1965 for the shocks No. 1 - 7 the highest densities are accumulated along the axis $p_{2}$, plotted in Fig. 2 and running over Praha along the river Sazava, and along $p_{4}$ in the direction $N W-S E$, continuing then north-wards in the southern part of $p_{1}$ (the Boskovice furrow). Another concentration occurs at the crossings $\left(p_{1}, q_{3}\right)$ and $\left(p_{1}{ }^{\prime \prime}, q_{2}\right)$ the Labe (Elbe) fault system and that of Iron Mountains (zelezne hory)). Further concentrations appear at the crossing $\left(p_{3}, q_{2}, r_{5}\right)$ (basins in South Bohemia) continuing northwards along $r_{s}$ and toward the north-west along the range of Šumava (Böhmerwald). Areas of higher densities along $q_{1}$ in the direction $N E-S W$ (running through densily faulted zones at the Barrandian $N W^{\prime}$-margin) and at the crossing $\left(p_{1}{ }^{\prime}, q_{+}\right)$(in the zone of the fault system of Luzice in the north of the Czech Cretaceous table). Changes of the frontiers associated with the period of World War II are responsible for the reduced number of observations available in the zones $q_{1}{ }^{I I I}$ and $q_{1}{ }^{\text {IV }}$ (fault zone systems in the south-east of the Ore Mountains (Krusne hory)). 
Interesting is the relationship of the calculated zones of higher mobility with the position of foci catalogued in Karník, V., Michal, E., Molnar, A., $1957\left(p_{3}, q_{2}, r_{5}\right)$ mentioned above. Along $q_{2}$ there is a number of foci situated in the region of the Bohemian-Moravian Highlands with a concentration at Jihlava (Iglau). Along the zones $p_{3}$, and also a parallel one lying on the Bavarian side, a number of foci is reported. Relatively many epicentres are located along $r_{6}$ (statistical representation of the Czech great quartz lode) with an accumulation in the region $\dot{u}$. As already indicated, $a$ high number of foci is accumulated in the Ore Mountains (Krusne hory) region near the zones $q_{1}{ }^{\text {III }}$ and $q_{1}{ }^{1 \mathrm{~V}}$ and their crossing with $r_{6}$ in the swarm region $c$. The group $d$ of epicentres in North Bohemia finds itself at the extrem ities of the zones $q_{3}$ and $q_{4}$, respectively. Many of historical shocks are situated along $p_{1}$, including in the south-east the active region $e$. In Central Bohemia historical foci are associated with the rather complicated $(p, q)$ configuration in the $N W$-part of $p_{2}$. A number of shocks was observed at Kutna Hcra (Kuttemberg) closely at the intersection $\left(p_{1}, q_{3}\right)$. At least a part of them, similarly as in the case of Jihlava (Iglau), may be related to the ore mining in the both places. Some historical shocks lie also along the $r_{1}$ and $r_{2}$, respectively.

In papers (Babuska et al., 1965; Babuska, V., Ruprechtova, L., 1965) dealing with shocks No. 5 - 6 the authors detected an anomalous increase of instrumental magnitudes $M_{L H}$ occuring for the stations situated $W-N W$ of the focus, i. e. a tendency analogous to the macroseismic anomaly. This azimuthal dependence of instrumental magnitudes emphasized specific conditions in the deep structure of the Bohemian Massif affecting the propagation of surface waves even at relatively distant stations $\left(\Delta_{\max }=\right.$ $=22.7^{\circ}$ ). The tendency of increasing magnitudes may be observed for the stations situated in the Hercynian and Caledonian parts of Europe.

As for the aftershock No. 3' and the earthquake No. 8, the distribution of observations fits fully the scheme given in Fig. 2, too.

3. Distribution of observations of the main shocN of Friuli, Italy, May 6, 1976, in Bohemian Massif.

Several times in the history (Karník, V. et al.. 1957) the Bohemian Mssif was macroseismically shaken by major earthquakes (with magnitudes going over 6 magnitude units) originated in the southern units of the East Alps, namely in the Carnic and Julian Alps, respectively. 
The shock named above was macroseismically felt far in the north off the Bohemian Massif. In this unit it was observed with top intensities in a few cases reaching $6^{0}$ MSK (Procházková, D. et al,, 1977). According to Italian seismologists (Giorgetti, F., 1976) the parametres of the shock were $46^{0} 17^{\prime} \mathrm{N}, 13^{0} 07^{\prime} \mathrm{E}, H=200009 \mathrm{UT}, I_{0}=10^{0} \mathrm{MSK}$, $M=6.4, h=7.8 \mathrm{~km}$; after C.S.E.M. $46.36^{0} \mathrm{~N}, 13.28^{\circ} \mathrm{E}, I_{0}=9^{0}-10^{0} \mathrm{MSK}$ and $M=6.7-7$.

Already the first information proved the transverse character of the macroseismic field with anomalously small attenuation toward the north (typical also for strong historical earthquakes occurred in this regicn), similar to the cases dealt with in II, 3 .

In Czechoslovakia the collection of information covered the whole area, where observable effects could be exprected (Giorgetti, F., 1976; Kárník, V. et al., 1977) ; thus, apart of positive also negative reports have gatinered. The former ones were available in 2588 cases from 459 localities. The analysis has been done and published (e. g. (Giorgetti, F., 1976; Kárník, V. et al., 1977; Kárník, V. et al., 1976)).

In the present paper only the distribution $f$ observations in the Czechoslovak territory after (Giorgetti, F., 1976) is considered in relation to the scheme given in Fig. 2. The inclusion of the said set of points caused practically no noticeable change in the statistical $(p, r, s)$-scheme; in a number of cases it was possible to extend, complete or make more accurate some regression lines as derived for shocks No. 1-4. These supp!ements are expressed in Fig. 2 by dashed lines.

The epicentral distance range for Bohemia and Moravia falls between 270 and $540 \mathrm{~km}$, i. e. cnsiderably more than for No. 1-4. In Slovkia the shock was fet only in Bratislava and Kuity, close to the south-western end of the Peripieninian lineament PL and the Lednice zone LZ, respectively (Figs. 1-5). There are no observations south-east of LZ.

The ccmparison of the density distributin of points with those found in (Zátopek, A. 1948 a) and (Babuška, V., Ruprechtová, L., 1965) shows in all cases maximum densities in the Neogene South Bohemia basins (neighbourhood of the $\left(p_{3}, q_{2}, r_{5}\right)$-intersection, focal area $a$ ), in Central Bohemia the fractured area closed by the zones $\left(p_{1}, q_{1}, p_{2}^{\prime}, q_{1}\right)$, cf. II, 2, and in the middle of the zone $q_{1}{ }^{\text {III }}$ along the fault zone in the south-east of the Ore Mountains (Krusné hory); systems $q_{1}{ }^{\mathrm{IiI}}$, $q_{1}{ }^{\text {IV }}, q_{1}{ }^{\prime \prime}$ and $q_{1}$ are well characterized in all cases and so $p_{1}{ }^{\prime}, p_{1}{ }^{\prime \prime}$ and partly $p_{1}$ (the last in its NW-part; in the SE-part the covering is rather poor); the zone $p_{2}$, very strongly pronounced for shocks No. 1-8; zones 


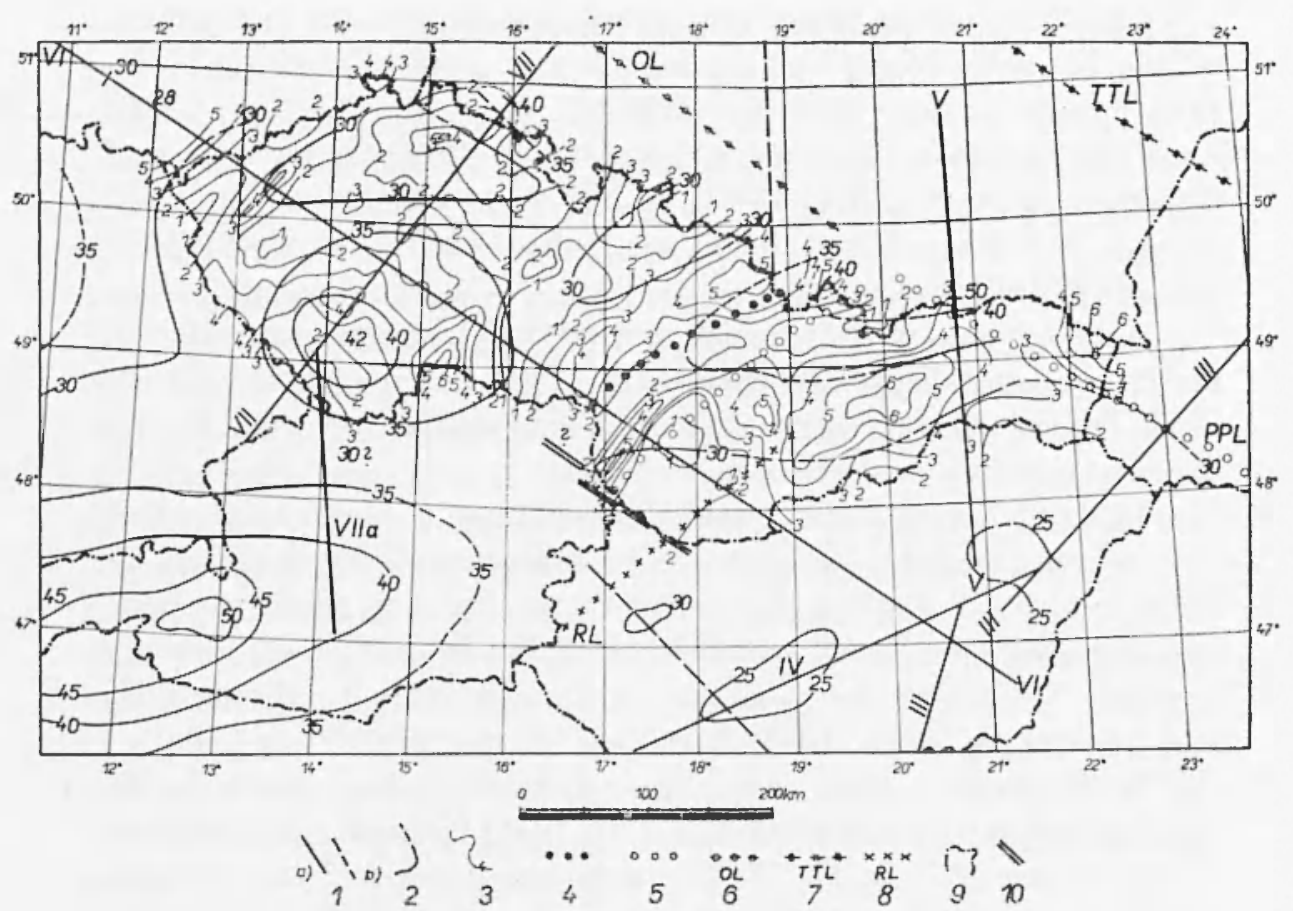

Fig. 5. Distribution of isolines of derivations of the vertical (in arbitrary units) in the Czechoslovak territory: la, $b$ - deep seismic sounding profiles; 2 - isolines of depths of the Moho; 3 - isolines of reduced deviations of the vertical; 4 - fault zone of Lednice; 5 - Peripieninian lineanent; 6 - Odra (Oder) lineament; 7 Tornqvist-Teisseyre lineament; 8 - Raab line; 9 - state frontiers; 10 - supposed zone reflecting seisnic energy of east-alpine earthquakes downwards.

$r_{1}, r_{2}, r_{5}$ and $r_{6}$ are cleary indicated, though with comparatively small numbers of observations (in the eastern part it was possible to trace mobile zcnes $p_{5}$ and $r_{4}$ in the active region $/$, see II, 2); striking is the small clensity of observations along $p_{+}$, and the southern part of $r_{\mathrm{l}}$, where (cf. II,2) for shocks No. 1-7 the highest densities were found. Surprisng is the case of Friuli the appearence of areas («shadow zones») with observations missing: a belt running on the northern side of $p_{1}$ from $r_{2}$ toward the north-west and then along $q_{3}$ to the south-west up to $p_{3}$; another empty area finds itself in the neovolcanic region of NW-Bohemia, and a third one occupies a part of the Cretaceous Table in NE-Bohemia in the northeast of $p_{1}$. 
Except the Carpathian foredeep CF (Fig. 1), the main shock of Friuli did practically not penetrate into the Carpathians.

4. Macroseismic field of other major European earthquakes in the Bohemian Massif.

Two earthquakes of 20 th century with foci situated west of the Bohemian Massif yielded a possibility to examine their macroseismic effects and distribution observations with regard to the scheme of the mobilc zones represented in Fig. 2:

a) the «Middle-European» earthquake of 16 November 1971, $48^{0} 11^{\prime} \mathrm{N}, 8^{0} 35^{\prime} \mathrm{E}, I_{0}=8^{\mathrm{n}} \mathrm{MCS}$ (Sieberg, A., 1932), (cf. also (Zatopek, 1948 a).

b) the earthquake in SW-Germany of 27 June $1935,48^{\circ} 03^{\prime} \mathrm{N}$, $9^{0} 28^{\prime} \mathrm{E}, I_{0}=8^{0}$ MCS (Hiller, W., 1936).

The focal depth of shocks was estimated (Karník, V., 1971) to be between $15-42 \mathrm{~km}$. Both earthquake emphasize, along the fault zones indicated in Fig. 1 (in the peripheral parts of the Bohemian Massif in the west, north and south), a similar shape of the area shaken. In the interior of the Bohemian Massif, the western part of Bohemia was afflicted macroseismically with hibher intensities grouped along the axis $q_{1}$ between the intersection with $p_{2}$ and $p_{1}$, respectively. Also the surroundings of the intersection $\left(p_{3}, q_{2}, r_{5}\right)$, i.e. the region of the South Bchemian basins, were macroseismically shaken, but not the zone $q_{2}$ itself. For the case $b$ ) almos all observations are situated in $q$-zones of West Bohemia, then along $p_{3}$. the NW-part of $p_{2}$ and along $p_{1}{ }^{\prime \prime}$; isolated observations lie also at the southern end of $r_{1}$.

It is thus possible to conclude that also in cases of extra-alpine sources the seismic energy was led by the same system of tectonic discontinuities as found for the east-alpine earthquakes. A further study of the selective way, in which the observed phenomena occur, may contribute to a better understanding of the behaviour of tectonic structures.

\section{CONTACT ZONE BETWEEN THE BOHEMIAN MASSIF AND THE CARPATHIANS}

\section{Generalities.}

The West Carpathians (Fig. 1) joing the East Alps at the river Danube between Vienna and Bratislava. Their main range proceeds in an arc, concave to the south, gradually in SW-NE, W-E and NW-SE. 
directions approximately up to the meridian $23^{\circ} \mathrm{E}$, where the East Carpathians begin (Fig. 1, 4-6).

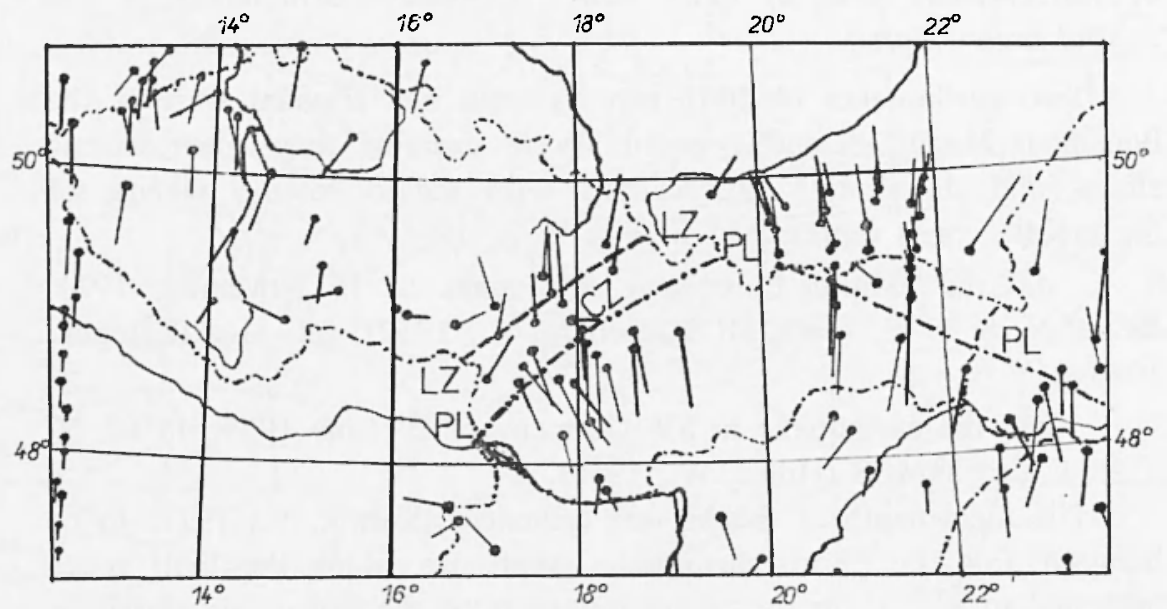

Fig. 6. Distribution of Weise induction vectors in the region: Note the inversion within the contact zone $\mathrm{CZ}$ and along the eastern branch of the Peripieninian lineament PL.

The West Carpathians are divided into the Outer (Flysch) Carpathians $\mathrm{OC}$ and the Inner (Central) Carpathians IC, separated from each other by the narrow Pieninian cliff (Klippen) fault zone, comprising marine Jurassic and Cretaceous comp'exes, the Peripieninian lineament FL. This zone is associated with many gephysical effects.

The Outher Carpathians developed as a geosynclinal foredeep during the Late Mesozoic and Paleogene and were filled by Flysch materials of age ranging frcm the Late Cretaceous to the Oligocene. After intense processes $f$ folding, faulting and forming of nappe structures in the Miocene, the Flysch nappes were thrust over the Neogene of the Carpathian foredeep.

In the Inner Carpathians metamorphic crystalline complexes of the basement (Late Precambrian gneisses and schistes, interspersed with Variscan p!utons) were covered by Paleozoic complexes and the sedimentary cover of Mesozoic Formations. This sequence with a part of the basement rocks was intensively ldlde and faulted during the Late Cretaceous. The newly created nappe formations were displaced to 
considerable distances. In the Eocene thick Flysch deposits resulted from the subsidence in the northern part of the Inner Carpathians. Their present structure was mostly created during the transition Paleogene-Neogene with large undulations and subsidences. Crystalline cores of the Inner Carpathians were lifted up. In the Neogene mostly only radial faulting occurred. The Neogene strata find themselves in the Outher Carpathian fcredeep $\mathrm{CF}$, in the Pannonian basin $\mathrm{PB}$, and extend frm the south into the central part of the Carpathian arc and in the intermontane depressions. Neogene sedimentary rocks are interbedded with Miocene to Pliocene volcanics in Central and South Slovakia, North Hungary and East Slovakia (with a continuation eastwards in the East Carpathians).

\section{Seismicity of the West Carpathians.}

The scismicity of the West Carpathians (Kárník, et al., 1957; Kárník, that of the East Carpathians (region of Vrancea!). In the West CarpaV., 1971) is comparable with that of the East Alps, but is lower than thians frequent small shocks are very shallow, of ten caused by movement of small block, influencing the shape and size of the macroseismic field (Zätopek, A., 1939; Kárník, V., 1960). The highest intensities may exceptionaliy reach or pass slightly over $9^{0} \mathrm{MSK}$, i.e. the maximum magnitudes near 6 magnitude units. Many of the active zones are connected with the Peripieninian lineament PL, comprising (Fig. 1) two branches oriented SW-NE and NW-SE, respectively (the latter continues in the Soviet East Carpthians). On the inner side of the Peripieninian lincament in the West Carpathians the epicentres concentrate in the arcas dcnoted in Fig. 1 with $g-k$; g-region of the Little Carpathians (Malé Karpaty) and Brezová Mountains (Brezovské pohorie), $h$-region of Żilina, $i$-Spis region, $j$-Vranov region, $k$-Humenné region. Typical small shocks are frequent in the territory of the USSR along the continuation cf neovolcanic zone mentioned above. As for other regions may epicentres are scattered in Central Slovakia -- region $m$; very active is the northern bcundary of the Pannonian basin, represented in Fig. 1 by the region l-Komárno-Budapest. The great Kománo earthquake of 1763 with $I_{0}=9^{\circ}-10^{\circ} \mathrm{MCS}$ is considered to be the strongest shock in the region of the West Carpathians. Intensities of $9^{0} \mathrm{MCS}$ are attributed to several schocks in the northern part of the region $g$, and of $8^{0}-9^{0}$ to the region $h$. All of the foci in the West Carpathians are situated in densily fractured 
zones and/or in neovolcanic areas. The high intensities reported in the region $m$, may conncted with ore mining and thus are mostly only of lccal importance.

The contact zone $\mathrm{CZ}$, where, as shown in part II, 2 of the present paper, also observations of east-alpine earthquakes die out, appears almost aseismic. Observations of shocks bound to regions $g, h$, and $l$ seem to indicate a higher attenuation of seismic energy in this zone, though the strongest of them display a transverse character of macroseismic field, elongated in the direction NW-SE.

\section{Crustal structure of the region and of the contact zone CZ.}

A simlified scheme of the Moho, resulting from explosion seismology (deep seismic sounding on international and national profiles, evaluation of quarry blasts) is sketched in Figs. 1, 4 and 5. A thin crust is typical for the Pannonian basin PB (minimum thickness $25 \mathrm{~km}$ ) and the south and south-western part of the West Carpathians; a thick crust is typical for the Pannonian basin PB (minimum thickness $25 \mathrm{~km}$ ) and the south and south-western part of the West Carpathians; a thick crust is typical for the southern part of the Bohemian Massif (maximum thickness $42 \mathrm{~km}$ ).

The method of continuous profiling, used mostly in Central and East Europe, allows to determine, apart from the depth of the Moho and other crustal discontinuities, also the position and character of pronunced fault zones and to delimit the structural blocks of the crust (Sollagub, V. B., et al., 1972). A satisfactory agreement found on profiles VI and VII with the mobile zones described in paper (Zatopek, A., 1948 a may thus be seen as its experimental verification.

In Fig. 3 the contact zone $\mathrm{CZ}$ is represented with the adjacent parts of the Bohemian Massif (left) and the southern part of the West Carpathians (right). A jump of $7-8 \mathrm{~km}$ was found between the respective levels of the Moho at this contact (about $36 \mathrm{~km}$ in the Bohemian Massif and $28-29 \mathrm{~km}$ in the West Carpathians) lying in the deep fault zone of the Peripieninian lineament PL. Corresponding jumps were stated in the eastern branch of the lineament at its cross-sections with international profiles $\mathrm{V}$ ( $10 \mathrm{~km}$, see Fig. 1) and III (over $20 \mathrm{~km}$, situated in the USSR).

The neighbouring fault zone LZ in the west, i. e. the Lednice zone, was discovered as a zone penetrating down to the Moho, too.

The deeper-seated block structure between LZ and PL proceeds 
towardsthe north-east; at the surface the zone is covered by mighty layers of Neogene sediments and is characterizer by a pronounced negative Bouguer gravity anomaly. The surroundings of the Lednice zone LZ and the crystaline in the adjacent part of the Bchemian Massif are conspicuous with the high positivee magnetic anomaly, which disappears east in the transition over the Peripieninian lineament. Measurements in a system of national profiles and the evaluation of quarry blasts records it was fcund that this zone is formed by individual blocks plunged to greated depths (36-38 km) varying from blcck to block. A similar structure was found in some places neigh-bouring on the Lednice zone from the west below the Carpathian foredeep CF (Beranek, B., 1971; Beranek, B., Zatcpek, A., 1975; Zatopek, A., 1975).

Relative ve'ocities of vertical component of recent crustal movements grcwing up to $4 \mathrm{~mm} /$ year with either upheavals or subsidences prove a relatively high mobility of the contact zone (Vyskcil, P., Kopecky,A., 1974).

In (Bursa, M., 1969) it was shown that the vectors of the deflections of the vertical after removing the effects of topography exhibit close correlaticns with the block structure. This can be well observed in Fig. 5 in the SW-part of the Peripieninin lineament PL, where the high gradients of the isolines indicate a local increase in geoid curvature.

Concerning the heast flow in the contact zone an incrase was found from about $55 \mathrm{mWm}^{-2}$ in the south-west to about $80 \mathrm{mWm}^{-2}$ in the north-east (Ostrava-Karvina coal basin) (Cermak, V., 1968).

An astonishing phenomen connected with the contact zone $\mathrm{CZ}$ in a peculiar distribution of electric conductivity expressed in the inversion of Wiese induction vectors (Wiese, H., 1965; Praus, O., 1971; Jankowski, J., et al., 1975) within the contact zone CZ. on the outer side of the Peripieninian lineament (Fig. 6). This striking behaviour was stated also along the eastern branch of the lineament and could be compared with the effect caused by a linear electric current conductor the axis of which would be situated parallelly to the Peripieinian lineament PL in a depth of $24.40 \mathrm{~km}$ (Jankowski, J., et al., 1975)

Broader relationships between the local geophysical fields bound to the contact zone $\mathrm{CZ}$ and the corresponding characteristics on a regional scale of $\mathrm{Fg} .1$ may be estimated in Fig. 4, where the distribution of Bouguer gravity anomalies, seismically active zones, geomagnetic anomalies, Wiese induction vectors along profile VI, and some other informa- 
tion are presented together.

In general, the distribution of positive and negative Bouguer gravity anomalies corresponds to the areas with a thin and thick crust, respectively. In the Alps the axis of maximum negative (Makris, J., 1971) anomalies coincides fairly well with that of the outher topography and the relief of the Moho. In the West Carpathians the axis of the maximum negative ancmalies follows the Peripieninian lineament along its western branch up to the region of the High Tatra (Ibrmajer, J., 1966). Further to the east this axis and the maximum depths of the Moho are shifting to the north (Ney, R., 1975) off the main mountain range into the Flysch zone of the Outher Carpathians. The Peripieninian lineament is here not accompanied by deep structural mass defects.

In the Inner Carpathians, in general, the regional gravity anomalies indicate, in agreement with deep seismic soundings and the pattern of derivatcins of the vertical (Fig. 5), a comparatively uniform thinning of the crust to the minimum of $25 \mathrm{~km}$ as found in the Pannonian basin.

It should be mentioned that the principle of isistasy is valid over larger parts of the region studied, but with many local deviations. The Airy model seems to be adequate only on a restricted scale.

In agreement with geological findings (Mahel, M., et al., 1974) and geodetis evidence (Cimballrúk, M., et al., 1967), recent crustal movements with vertical compcnent of velocity over $5 \mathrm{~mm} /$ year been ascertained in the Danubian Lowland and show a tendency to grow toward the Pannonian basin.

Epicentral zones are indicated in Fig. 4 by dots. Seismic characteristics of the Bohemian Massif as an active area and the selective propagation of the energy from east-alpine and some other foci in a was confirmed by deep seismic sounding, were analyzed in part II. The stable system of statistically found discontinuities, the existence of which instrumentaily assessed higher magnitudes of east-alpine earthquakes in stations situated in the Hercynian and Caledonian parts of Europe is an effect which would pay a further study.

We introduce a few examples of earthquakes associated with the Peripieninian linement: Dobra Voda (known as Jokeo) 1906 (region g), $I_{0}=9^{0} \mathrm{MCS}$; zilina 1858 (region $h$ ), $I_{0}=8^{0}-9^{0}$ MCS; Strazske 1941 (region $k$ ), $I_{0}=7^{0}$. As already mentioned, focal depths in the West Carpathians can rarely be estimated over $10 \mathrm{~km}$. The seismic zone connected with the western branch of the Peripieninian lineament continues in the SW-direcion as far as to the Po lowland in North Italy. 
With regard to the poor propagation of the east-alpine shocks into the West Carpathians, a «seismic mirror", i. e. a fault zone, indicated in Figs. 4 and 5, was assumed (Zatopek, A., 1957), reflecting the energy coming from the east-alpine foci downwards. Unfortunately, experimental data from this important contact zone between the East Alps and the West Carpathians are missing.

Zones of positive geomagnetic anomalies are often typical for contacts of bigger tectonic units. Such an anomaly (Fig. 3) was already mentioned in the contact zone between the Bohemian Massif and the Carpathians. High magnetic anomalies occur in zones of intesive metamorphism (e. g. in East and Central Bohemia) or are accompanying the zones of young-Tertiary volcanism. The latter ones are often connected with frequent small shocks in the neighbourhood of the eastern branch of the Peripieninian lineament.

The distribution of Wiese induction vectors in the wider region far enough from the contact zone $\mathrm{CZ}$ and the Peripinian lineament (cf. Figs. 4 and 6 ) indicates the presence of an exstended and tectonically oriented deep-seated anisotropy of electrical conductivity, which sometimes is considered (Sollagub, V. B., et al., 1972) in connection with the asthenospheric channel of lower seismic velocities.

Concerning geothermal characteristics of the studied region the recently issued paper Cermak, V., Hurtig, E., 1977)yields the most comprehensive information. Inside the Bohemian Massif the heast flow is rather low $\left(40-60 \mathrm{mWm}^{-2}\right)$ with a minimum corresponding to the to the maximum crustal thickness and the maximum in the thermal area of North Bohemia. In the Carpathians the heast flow increases from $50-60 \mathrm{mWm}^{-2}$ in the outer Flysch zone to about $70 \mathrm{mWm}^{-2}$ in the main folded units of the Inner Carpathians and a rapid increase occurs in the central intermcntane depressions to $100 \mathrm{mWm}^{-2}$ and more in the Pannonian basin. These results are Conform with the conditions of themodel of Ney (Ney, R., 1975), supposing some kind of subduction in the some zone of the Peripieninian lineament.

\section{CONCLUSION.}

The existence of a stable statistically derived pattern of zones of higher mobility in the Bohemian Massif, where the energy of earthquakes originated in the north-eastern part of the East Alps is selectively 
propagated northwards, was confirmed by further abservations. The interpretation of this anomaly by guided waves, leading the energy from a deep interface to the surface along almost vertical fault zones, is suported by the results of explosion seismology conducted in the region. The mobile zones have been identified as surficial indications of deep fault systems reaching in some cases down to the Moho and perhaps partly into the mantle. Some of these zones have been found seismogenetic.

Particular attention has been paid to the contact zone $\mathrm{CZ}$ between the Bohemian Massif and the West Carpathians, which is separated in the west frm the Bohemian Massif by the Lednice deep fault zone, and the east from the Inner Carpathians by the Peripieninian lineament, which was found to be the most conspicous feature in the West Carpathians.

Gravimetric, geomagnetic, magnetotelluric and geothermic effects are associated with the contact zone, which is formed by adeeperseated system of blocks situated on the outher side along the Peripieninian lineament. Here jumps of many kilcmetres occur in the level of the Moho at the transition from the thin crust inside the Carpathian arc to the thick crust outside. A strikingly pronunced line of inversion of Wiese induction vectores within the contact zone, continued eastwards outside the Peripieninian lineament, suggests a particular distribution of electric conductivity in this zone. Seismic activity, associated with the Peripieninian lineament, appears predominantly on its inner side, where, in the western part, some destructive shocks have been catalogued.

A brief description of characteristics of the regional geophysical fields is given for comparison with the more or less small scale character of those connected with the contact zone $\mathrm{CZ}$.

A systematic geophysical study with a complex of methods and a gcophysical synthesis appear necessary in all contact zones between individual big tectnic units of the region, which may be considered as one of the clue areas of European tectonics. 


\section{REFERENCES}

V. BabUŠKA, L. Ruprechtoví, 1965. - Contribution to the Investigation of Eastalpine Earthquakes, «Tr. Inst. Geophys. Ac. Tch. Sc.», No. 225.

V. Babuška, L. Ruprechtoví, O.Zenklová, 1965. - East-alpine Earthquake of 2nd December 1963, "Studia geophys. et geod.», 9, p. 302.

Beranek B., 1971. - Study of the Velocity Conditions in the Earth's Crust in the Regions of the Bohemian Massif and the Carpathian System along International Profiles VI and VII, "Studia geophys. et geod.», 15, p. 316.

Berínek B., Dudek A., 1972. - The Results of Deep Seismic Sounding in Czechoslovakia, "Zeitschr. f. Geophys.», 38, p. 415.

Berínek B., Zńtopek A., 1975. - On the Crustal Structure in Czechoslovakia and the East-alpine Region, "Techn. and Econ. Stud.», Spec. Issue, Ser. D, Nr. 10, p. 187.

BurŠA M., ERCR. - Effect of Removed Topography and Condensation on Deflections of the Vertical on the Territory of Czechoslovakia, "Trav. Inst. Geophys. Ac. Tch. Sc.», 17, p. 45.

Cевмák V., 1968. - Terrestrial Heat Flow in Czechoslovakia and Its Relation to Some Geological Features, "Internat. Geol. Congr. Rep.», Proc. Sect. 5, p. 75.

C1rmak V., Hurtig E., 1977. - Preliminary Heat Flow Map of Europe 1: 5000000. Explanatory Text, «IASPEI, Int. Heat Flow Commission, Czechosl. Ac. Sci. Praha, Central Earth Phys. Inst. Potsdam, Ac. Sci. CDR», Potsdam.

CERMÁK V., 1974. - Deep Temperature Distribution along the Deep Seismic Sounding Profile across the Carpanthians (Model Calculations), «Acta Geol. Sei. Hung.», 18, p. 295.

Cimbalnik M., Kruis B., Vyskočıl P., 1967. - Recent Crustal Movements in the $C S S R$, «Sstudia geophys. et geod.», 11, p. 354.

Giorgett F., 1976. - Macroseismic Map of May 6 Earthquake of Friuli, «Proceedings of the Meting on Friuli earthquake», Udine, Dec. 4-5.

F. Herıtsch 1911. - Transversalbeben in den nordöstlichen Alpen, "Mitt. di Erdbebenkomm. d. Akad. d. Wiss. Wien», N. F.. 40.

Hiller W., 1936. - Oberschuäbische Erdbeben an 27. Juni 1935, "Württ. Jahrb. f. Statistik u. Landeskunde», 1934-1935, Stuttgart.

V. Kárník, E. Michal, A. Mol.NÁr 1957. - Erdbebenkatalog der CSR, «TR. Sc. Inst. Geophys. Acad. Tch. Sc., 69.

V. Kর́nNík. - Seismicity of the European Area, Part 1, 1968; Part 2, 1971, Academia Praha. 
KÁrRník V., 1960. - Die Seismizität der Westkarpaten, «Tr. Inst. Geophys. Ac. Tch. Sc.», 134.

Kárník V., Prochìzkovà D., Schenková Z., Ruprechtovâ L., Dudek A., Drimmel J., Schmedes E., Leydecker G., Rothe J. P., Guterch A., Lewandowska H., Meyer-Rosa D., Cvijanović D., Kuk V., Gıorgetti F., GrüNTAL. G., Hurtig E., 1976. - Map of Isoseismals of the Main Friuli Earthquake of May 6, 1976, "Proceedings of the Meeting on the Friuli earthquake», Udine, Dec. 4-5.

Kárník V., Prochazkovâ D., Ruprechtovà L., Schenkovì Z., 1977. - Macroseismic Field of the Friuli Earthquake of May 6th, 1976, "Tr. Inst. Geophys. Ac. Tch. Sc.», 25, No. 483.

F. KAUTSKY 1924. - Die Erdbeben des ösllichen Teiles der Ostalpen, ihre Beziehungen zur Tekınik und den Schu'ere-anonalien, «Mitt. d. Erdbebenkomm. d. Akad. d. Wiss. Wien", N. F. 58.

Ibrninjer I., 1966. - Gravimetrická mapa CSSR, 1: 1, 000 000, «Ùùg». Praha.

Jankowski J., Szimanski A., Pěč4ví J., Praus O., Petr V., 1975. - Electromagnetic Induction Study on DDS Profile No. V (Carpathians), «Studia geophys. et geod.», 19, p. 95.

MAEHL H., et al. 1974. - Tectonics of the Carpathia-Balkan Regions (Explanations to the tectonic map of the Carpathian-Balkan Regions and their foreland), «Geol. Inst. D. Stur», Bratislava.

Makrie J., 1971. - Aujbau der Kruste in den Ostalpen aus Schwereremessungen und die Ergebnisse der Refaraktionsseismik, Hamburger geophys. «Einzelschr., Geophys. Inst. Univ. Hamburg», 15.

V. MifKa, E. Trapp 1941. - Das Ebreisclisclorfer Beben vom 8. November 1938, «Sitzungsber. d. Akad. d. Wiss. Wien», math.-nat. Kl., Abt. Ila, 150, H. 1-4.

Ney R., 1975. - Tectogenesis of the Carpathians in the Light of New Tectonics of the Earlh's Globe, "Math. i Prace Inst. Geofiz. (Publ. Inst. Geoph. Pol. Ac. Sci.)», 82, p. 95.

Praus O., 1971. - Electric conductivity in the Earlh in Czechoslovakia sludied by magnetotelluric and geomagnetic methods, «UMP Final Report», 162. Academia Praha.

Procházkovâ D., Ruprechtovà L., Schenkovì Z., Dudek A. - 1977.-Macroseismc Effects of the North-Italian Earthquake of May 6th, 1976, on the Territory of Czechoslovakia, "Studia geophys. et geod.», 21, 293.

R. SCHWINNER 1929. - Geophysikalische Zusammenhänge zwischen Osialpen und böhmischer Masse, «Gcrl. Beitr. z. Gcophys», 23, p. 35.

A. SiEBERG 1932. - Erdbebengeographie in Gutenberg's Handbuch der Geophysik IV, pp. 731-733, Gebr. Bornträger, Berlin.

Sollogun V. B., et al 1972. - The crustal structure of Central and Southeastern Europe based on the results of explosion seismology, edited by G. Szenàs, Geofız. Közlem., Spec. edition, p. 172. 
E. Suess 1885. - Das Anilitz der Erde, I, 106, 228, Wien.

VysKoČıl P., KopeckY A., 1974. - Neotectonics and Recent Crustal Movements in the Bohemian Massif, "vÙGTK", ser. 4, Praha.

WIESE H. Geomagnetische Induktionspleile in der CSSR, hervorgerufen durch grossräumige Leit/ähigkeitssirukiuren, «Studia geophys. et geod.», 9, p. 415.

A. Zńtopeк 1948a. - The propagation of east-alpine earthquakes in the Bohemian Mass (in Czech, abstract in English), «Publ. Cs. St. úst. geolys.», Tr. spec. No. 3, Praha.

A. ZÁtopé, 1948b. - Sur la propagation des seismes se produisant dans les Alpes orientales a travers le Massif de Boheme, "Publ. du BCIS», Ser. A, Tr. Sc., 17. p. 123.

A. Zńtop'ек, 1957. - Zu einigen Problemen der Krustendynanik im Karpatengebiet, «Geofiz. Közlem.», 8, p. 106.

Zর́topeк A., 1975. - Geophysical Synthesis and Crustal Structure. "Veröff. Zentr. Inst. Phys. d. Erde", 31, p. 291.

Zи́тоРек A., 1939. - Erdbebenbeobachtungen in der Slowakei und ehem. Karpatenrussland 1939-1938 (in Czech, abstracts in German and French), «Spec. pr. St. uist. geofys.», 2, Praha. 